\title{
COMPARISON OF CHEMICAL COMPOSITION OF FRESH AND FERMENTED CABBAGE JUICE
}

\author{
Liene Jansone*, Solvita Kampuse \\ Department of Food Technology, Faculty of Food Technology, Latvia University of Life Sciences and Technologies, \\ Rigas iela 22, Jelgava, Latvia, e-mail: liene.jansone@gmail.com
}

\begin{abstract}
White cabbage (Brassica oleracea var. capitata) is an affordable and available vegetable in local markets around the globe. It is a source of vitamins, micro and macro nutrients. The aim of this study was to compare the chemical composition of fresh and fermented cabbage juices from three different varieties. In this study vitamin $\mathrm{C}$ content, antiradical activity, total phenolic content, and total carotenes were determined. Results show a significant $(\mathrm{p}<0.05)$ influence of cabbage variety on vitamin $\mathrm{C}$ content. Fermentation process decreased vitamin $\mathrm{C}$ content in the variety 'Selma' but increased in 'Ramkila' and 'Kilpatons'. There were no significant differences between varieties ( $\mathrm{p}>0.05$ ) in the antiradical activity (by DPPH method) of fresh cabbage juice while fermentation process slightly increased it in varieties 'Ramkila' and 'Kilpatons' but significantly increased it in 'Selma' (from 96.66 for fresh to $189.54 \mathrm{mg} 100 \mathrm{~g}^{-1}$ on dry weight (DW) for fermented). There was no consistency in the antiradical activity by ABTS ${ }^{+}$method. Fermentation process slightly decreased it in variety 'Ramkila', significantly decreased it in variety 'Selma' (805.72 for fresh to

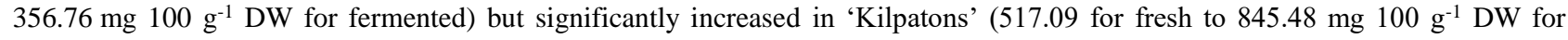
fermented). Fermentation process significantly influenced contents of total phenolic compounds in two varieties - 'Ramkila'

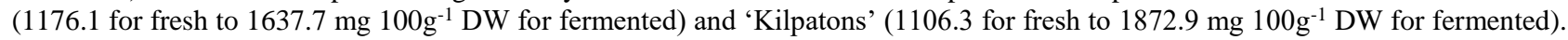
Results showed that white cabbage or sauerkraut is not a beneficial source of carotenes.
\end{abstract}

Keywords: fermented cabbage, antiradical activity, total phenolic content

\section{Introduction}

White cabbage (Brassica oleracea var. capitata) is an affordable and available vegetable in local markets around the globe. Annually cabbage and brassica vegetables are consumed approximately $6.3 \mathrm{~kg}$ worldwide (Rokayya et al., 2013) and more than $8 \mathrm{~kg}$ of white cabbage in Latvia per capita (Gailīte, 2018).

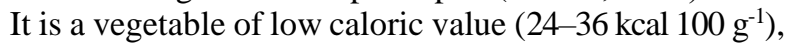

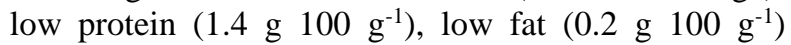
content, but high in minerals (such as potassium: $208 \mathrm{mg} 100 \mathrm{~g}^{-1}$, calcium: $46 \mathrm{mg} 100 \mathrm{~g}^{-1}$, magnesium:

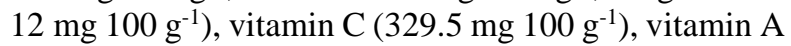
$\left(31 \mu \mathrm{g} 100 \mathrm{~g}^{-1}\right)$, dietary fibre $\left(3.0 \mathrm{~g}^{100 \mathrm{~g}^{-1}}\right)$ and water content (92 g $100 \mathrm{~g}^{-1}$ ). Cabbage contains moderate

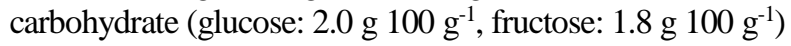
amounts, and have a high level of phenolic compounds including polyphenols (Rodriguez-Amaya, 2015). $\beta$-carotene content in cabbage ranged from 0.009-0.124 mg $100 \mathrm{~g}^{-1}$ fresh weight, total phenolics: 12.58-34.41 mg $100 \quad \mathrm{~g}^{-1}$ fresh weight (Singh et al., 2006). Total phenolic contents, antioxidant capacity, flavonoid content are influenced by many factors, including growing developmental stages (Šamec, 2011). Most common way to use cabbage is either fresh in soups and salads, or fermented - sauerkraut.

Sauerkraut fermentation is a dynamic biochemical system, where chemical composition and microbial ecology of the system are continuously changing (Lu et al., 2003). To ferment cabbage, varieties with the highest carbohydrate content with a sugar content of at least $4 \%$ are selected. Fermentation process using lactic acid bacteria in cabbage increases the content of vitamins, free amino acids and other physiologically active substances in the product, though the choice of starter and cabbage variety has a noticeable impact on chemical composition (Vatansever, 2017; Martinez-
Villaluenga et al., 2012). Spontaneous sauerkraut fermentation relies on a small population of lactic acid bacteria (LAB) (which are naturally present on fresh vegetables) and their metabolites. The process is divided into heterofermentative and homofermentative stages. In the first stage, the activity of heterofermentative Leuconostoc mesenteroides determines the quality of sauerkraut. Acid-tolerant Lactobacillus species takes over second homofermentative stage with decrease in $\mathrm{pH}$ (4.5-3.5) and accumulation of lactic acid. (Yoon et al., 2002; Lu et al., 2003). Consumption of sugars, $\mathrm{pH}$ reduction and acid production is very rapid in the first stage ( $\sim$ first 2 weeks) and slows thereafter and remains unchanged after day 30 (Yoon et al., 2002). Strains isolated during the first stage (day 1 to day 3 ) belong to genus Leuconostoc or Weisella, after that it is Lactobacillus strains (L. plantarum and L. brevis) (Yoon et al., 2002).

Biochemical tests showed that Leuconostoc and Weisella strains produce carbon dioxide from glycose as well as characteristic slime of dextran from sucrose. None of Lactobacillus (L. plantarum nor L. brevis) strains produce slime colonies on sucrose agar, and only $L$. brevis strain produces carbon dioxide (Lu et al., 2003). To ensure the correct sequence of LAB species, which is essential to achieve a stable product with typical flavour and aroma, producers choose to use LAB starter culture (Leuconostoc mesenteroides) as well as to reduce $\mathrm{NaCl}$ content as low as $0.6 \%$ (Viander et al., 2003).

Bacterial growth is involved in the metabolism of phenolic compounds and is compound dependent (Rodriguez et al., 2009; Alberto et al., 2012).

Fermentation process leads to formation of bioactive compounds (Palani et al., 2016). The influence of fermentation process on chemical composition in white cabbage has been done by Spanish researchers. It states 
that fermentation process increases ascorbic acid content, antioxidant activity and nitric oxide production inhibitory activity, though the choice of starter has a noticeable impact (Martinez-Villaluenga et al., 2012). For ascorbic acid formation, initial glucobrassicin levels in vegetables are important and is a reason why the amount of ascorbigen can significantly vary between different varieties (Wagner, Rimbach, 2009). The titratable acidity in sauerkraut ranges between $0.9-1.5 \%$ (Trail et al., 1996).

Consumption of fresh and fermented cabbage in Latvia is considerable. However little or no research was done to compare cabbage varieties grown in Latvia and how fermentation process affects their chemical composition.

The aim of this study was to compare chemical composition of fresh and fermented cabbage juices from three different varieties.

\section{Materials and Methods}

Experimental work was carried out in Latvia University of Life Sciences and Technologies, Faculty of Food technology.

\section{Sample preparation}

Three varieties of fresh cabbage heads were delivered by a farmer. Three $1 \mathrm{~L}$ bottles of sauerkraut juice from the same varieties were delivered by the same farmer. The varieties were: 'Selma' (with a light green firm head), 'Kilpatons' (with a greener, not so firm, head; sweet to taste), and 'Ramkila' (a big, very light, and very firm head with some spoiled leaves in between).

Cabbage heads were cleaned from outer, not-fresh leaves. The spoiled inner leaves of variety 'Ramkila' were removed. Segments (3 cm vide) were cut out of each head and juice was extracted with masticating slow juicer (Easyline, Villa-Verucchio model ELCJE6203235M).

\section{Chemical and physical analyses}

Vitamin $C$ was determined using iodine method T-138-15-01:2002 (Seglina, 2007) which determines reduced form of ascorbic acid (L-ascorbic acid). Experimental samples were mixed with $100 \mathrm{~mL} \mathrm{6 \%}$ $\mathrm{H}_{2} \mathrm{C}_{2} \mathrm{O}_{4}$ solution blended and filtered. $10 \mathrm{~mL}$ of filtrate was mixed with $2 \mathrm{ml}$ of $1 \%$ starch solution and titrated with $0.05 \mathrm{~m}$ iodine solution.

Preparation of extracts. Samples of fresh and fermented juices $(\sim 10 \mathrm{~g})$ of each variety were extracted with $20 \mathrm{~mL}$ of $80 \%$ ethanol by stirring on the magnetic stirrer for 45 minutes. Two repetitions were made. Ethanolic extracts were then filtered into $25 \mathrm{~mL}$ flasks and stored at $4 \pm 2{ }^{\circ} \mathrm{C}$ till further analysis. Extracts were used for the estimation of total phenolic contents and antiradical activities (DPPH; ABTS $^{+}$) (Rokayya et al., 2013).

Total phenolic content in extracts was estimated spectrophotometrically using Follin-Ciocalteu reagent according to Prasad et al. (2013) with some modifications. Three repetitions of $0.5 \mathrm{~mL}$ of extract were mixed each with $2.5 \mathrm{~mL}$ Follin-Ciocalteu reagent (diluted ten times with deionized water), left to react for
5 min. Then $2 \mathrm{~mL} 7.5 \% \quad \mathrm{Na}_{2} \mathrm{Co}_{3}$ were added and mixtures were left to react for another $30 \mathrm{~min}$. The absorption was read spectrophotometrically at $765 \mathrm{~nm}$ on Jennway 6300 (Baroworld Scientific Ltd., UK). The total phenolic content was determined using standard gallic acid calibration curve and results were expressed as milligrams of gallic acid equivalent (mg GAE $\left.100 \mathrm{~g}^{-1} \mathrm{DW}\right)$.

Antiradical activity was determined using $\mathrm{ABTS}^{+}$ (2,2-azino-di-3-ethylbenzothialozine-sulphonic acid) decolouration method and DPPH (2,2-diphenyl-1picrylhydrazyl) radical scavenging assay. The $\mathrm{ABTS}^{+}$ stock solution was made with addition of potassium persulfate as an oxidation agent (Rokayya et al., 2013) and left to react in the darkness for $12 \mathrm{~h}$. To obtain the working solution of $\mathrm{ABTS}^{+}$, the stock solution was diluted with phosphate buffered saline (PBS) to the absorption of $0.800 \pm 0.030$ at $734 \mathrm{~nm}$ (against the blank) on JENWAY 6300. Three repetitions of $0.05 \mathrm{~mL}$ sample extract were mixed with $5 \mathrm{~mL}$ of $\mathrm{ABTS}^{+}$solution, left to react for $10 \mathrm{~min}$ and absorptions were determined as had been described previously.

The DPPH radical scavening assay was done according to the method of Kriengsak et al. (2006) with some modifications. The stock solution was made by mixing $0.004 \mathrm{~g} \mathrm{DPPH}$ with $96 \%$ ethanol to the absorption of $1.000 \pm 0.02$ units against the blank on spectrophotometer at $517 \mathrm{~nm}$. Three repetitions of $0.5 \mathrm{~mL}$ sample extracts were mixed with $3.5 \mathrm{~mL}$ freshly made DPPH stock solution, left to react in the dark for 30 min and then absorption had been measured.

Total carotenes were determined using method described by Kampuse et al. (2015) with modifications. Samples of $5 \mathrm{~g}$ (with precision of $0.0002 \mathrm{~g}$ ) of fresh cabbage and sauerkraut juices were mixed with $20 \mathrm{~mL}$ $96 \%$ ethanol and stirred magnetically, after $15 \mathrm{~min}$ $25 \mathrm{~mL}$ of petrol ether (80-110) was added and stirring continued for another $60 \mathrm{~min}$. Samples were left to settle and results were read using UV/VIS spectrophotometer Jenway 6705.

\section{Statistical analysis}

The differences between results were analysed using two-factor analysis of variance (ANOVA) followed by Tukey-Kramer method. The obtained results were presented as means with standard errors. Differences among results were considered to be significant if $\mathrm{p}<0.05$.

\section{Results and Discussion}

Chemical composition of fresh and fermented cabbage juices varied among cabbage varieties which might be due to different initial physical characteristics (Thakur et al., 2017) as well as it is influenced by growing conditions, storing, fermentation process and many more factors (Kusznierewicz et al., 2008; Wagner, Rimbach, 2009; Palani et. al., 2016).

Vitamin C. Analysing obtained results, it was determined that there is a significant $(\mathrm{p}<0.05)$ influence of cabbage variety on vitamin $\mathrm{C}$ (Fig. 1) content, also fermentation process affected it differently in studied 
varieties. In two of analysed cabbage varieties vitamin $\mathrm{C}$ content increased after fermentation process 'Ramkila' (511.8 for fresh to $591.9 \mathrm{mg} 100 \mathrm{~g}^{-1} \mathrm{DW}$ for fermented) and 'Kilpatons' (522.6 for fresh to $671 \mathrm{mg} 100 \mathrm{~g}^{-1} \mathrm{DW}$ for fermented), while variety 'Selma' had a decrease in vitamin $\mathrm{C}$ after fermentation (809.7 for fresh to $672.4 \mathrm{mg} 100 \mathrm{~g}^{-1} \mathrm{DW}$ for fermented). Differences in results can be explained by enzymatic reactions of chemical compounds in varieties as described by Wagner et al. (2009) and MartinezVillaluenga et al. (2009). According to Thakur et al. (2017), ascorbic acid content increases during fermentation up to day 21, after which it gradually decreases in all varieties.

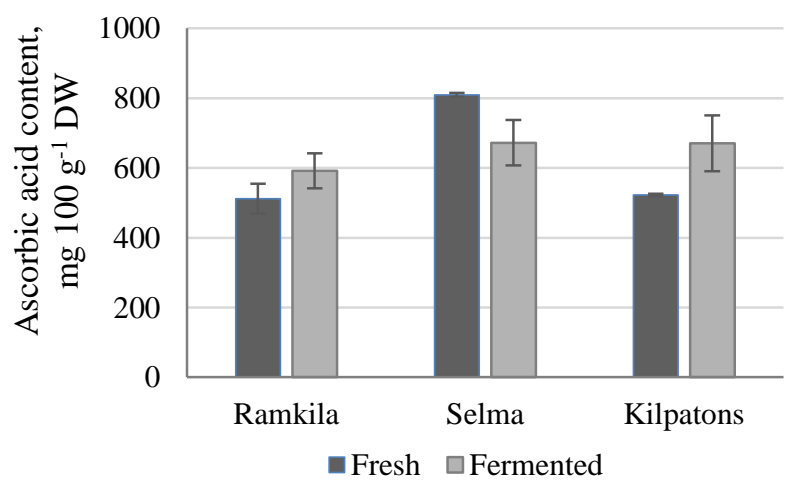

Figure 1. Ascorbic acid content in fresh and fermented cabbage juice, $\mathrm{mg}^{100} \mathrm{~g}^{-1} \mathrm{DW}$

The loss of vitamin $\mathrm{C}$ due to cabbage fermentation partially may be explained by ascorbic acid involvement in ascorbigen formation. It also may be influenced by the production process of sauerkraut - vitamin C depletion occur when vegetables are severely cut or shredded. Trimming of outer leaves, that contain more vitamin $\mathrm{C}$ than inner leaves, results in greater decrease in vitamin $\mathrm{C}$ than enzymatic breakdown by ascorbate oxidase, autoxidation and so on (MartinezVillaluenga et al., 2009). To avoid decrease of vitamin $\mathrm{C}$ in fermentation process, it is advisable to choose fresh cabbage heads with little or no damaged outer leaves and to control the fermentation process, time and temperature.

\section{Total phenolic contents}

Fermentation process significantly influenced total phenolic contents (Fig. 2) in two varieties - 'Ramkila' (1176.1 for fresh to $1637.7 \mathrm{mg} 100 \mathrm{~g}^{-1} \mathrm{DW}$ for fermented) and 'Kilpatons' (1106.3 for fresh to $1872.9 \mathrm{mg} 100 \mathrm{~g}^{-1} \mathrm{DW}$ for fermented). However, total phenolic content in the variety 'Selma' was not significantly $(\mathrm{p}<0.05)$ influenced by fermentation process (1603.5 for fresh to $1632.4 \mathrm{mg} 100 \mathrm{~g}^{-1} \mathrm{DW}$ for fermented). One of the reasons, as Kusznierewicz et al. (2007) have come to conclusion that antiradical activity initially increases during wounding or shredding for spontaneously fermented sauerkraut. Fermentation and chemical processes incurred by lactic acid can induce formation of novel compounds that can neutralize free radicals. However, metabolic pathways of biosynthesis or degradation of phenolic compounds by lactic acid bacteria have not been completely described (Rodriguez, 2009).

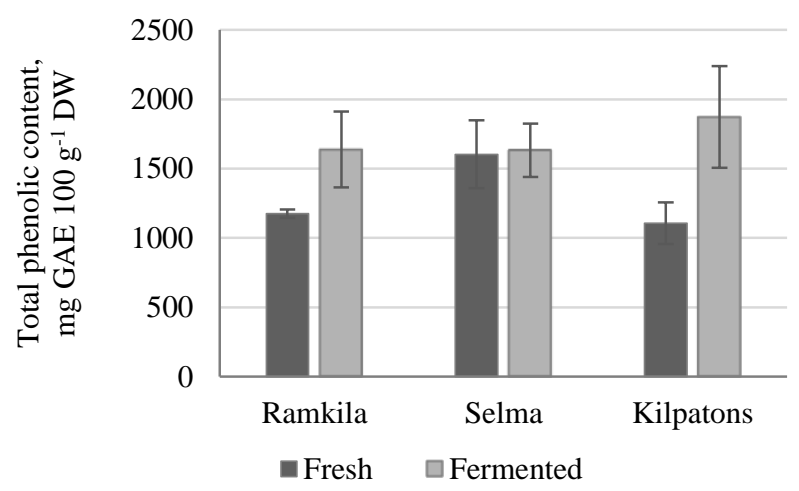

Figure 2. Total phenolic content in fresh and fermented cabbage juice, mg GAE $100 \mathrm{~g}^{-1} \mathrm{DW}$

\section{Antiradical activity}

Antiradical activity by $\mathrm{ABTS}^{+}$decolouration method showed significant ( $p>0.05)$ variations (Fig. 3). Variety 'Ramkila' (704.7 for fresh to $611.1 \mathrm{mg} 100 \mathrm{~g}^{-1} \mathrm{DW}$ for fermented) and 'Selma' (805.7 for fresh to

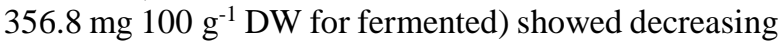
results, whereas in variety 'Kilpatons' antiradical

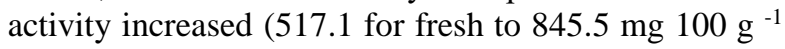
DW for fermented).

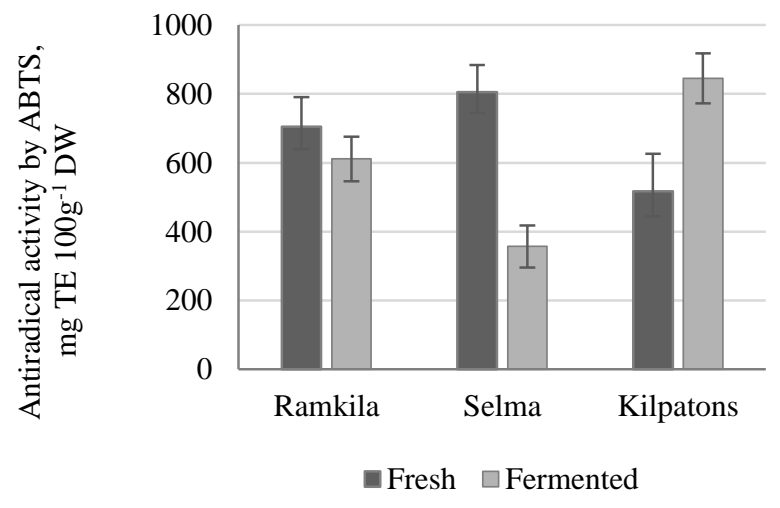

Figure 3. Antiradical activity by ABTS + in fresh and fermented cabbage juice, mg TE $100 \mathrm{~g}^{-1} \mathrm{DW}$

There were no significant differences between varieties $(\mathrm{p}>0.05)$ in DPPH radical scavenging assay in fresh cabbage juice, (95.9-98.5 mg $\left.100 \mathrm{~g}^{-1} \quad \mathrm{DW}\right)$. Fermentation process significantly increased the antiradical activity (138.7-189.5 mg $\left.100 \mathrm{~g}^{-1} \mathrm{DW}\right)$ and there were significant differences between varieties (Fig. 4), too ( $\mathrm{p}<0.05$ ). DPPH method is widely used to determine antiradical / antioxidant activity of purified phenolic compounds (Shalaby, Shanab, 2012). The overall content of phenols tends to increase which also can explain increase of DPPH antiradical activity. As concluded by Kusznierewicz et al. (2007), it is not 
always the case that fermenting rises antiradical activity and vitamin $\mathrm{C}$ content.

Different antiradical activity results can be explained by differences in radical assay methods. DPPH is sensitive to acidic $\mathrm{pH}$, samples react very slowly not reaching steady state after 8 hours, whereas $\mathrm{ABTS}^{+}$method has the extra flexibility to be used at different $\mathrm{pH}$ levels, samples react rapidly, reaching steady state within 30 minutes.

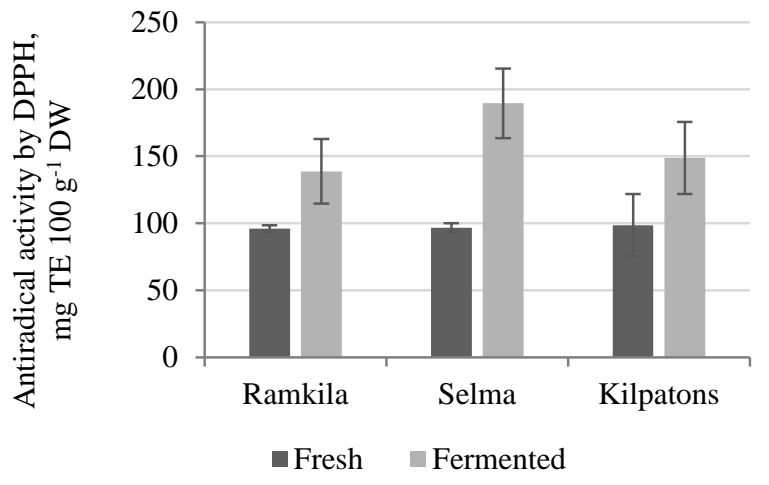

\section{Fig. 4. Antiradical activity by DPPH in fresh and fermented cabbage juice}

$\mathrm{ABTS}^{+}$assay measures the relative ability of antioxidant to scavenge the $\mathrm{ABTS}^{+}$generated in aqueous phase as compared with a water-soluble vitamin $\mathrm{E}$ analogue standard (Trolox) (Shalaby, Shanab, 2012) so it's radicals react with different compounds and show higher antioxidant capacity in cabbage juice (Šamec, 2011). The rise of $\mathrm{ABTS}^{+}$antiradical activity in variety 'Kilpatons' could be explained by different and more water-soluble compounds.

\section{Total carotenes}

Results showed that white cabbage and sauerkraut are not a beneficial source of carotenes, which is in agreement with the information reported by Singh (2006). Variety 'Ramkila' showed a decrease in total carotenes form 9.45 (for fresh) to $3.77 \mathrm{mg} 100 \mathrm{~g}^{-1} \mathrm{DW}$ (for fermented) and 'Selma' from 8.28 (for fresh) to $0.27 \mathrm{mg} 100 \mathrm{~g}^{-1} \mathrm{DW}$ (for fermented), while variety 'Kilpatons' had an increase from 4.36 (for fresh) to $10.35 \mathrm{mg} 100 \mathrm{~g}^{-1} \mathrm{DW}$ (for fermented).

\section{Conclusions}

Fermentation process positively influenced DPPH radical scavenging activity in tested cabbage varieties, however there is no such trend in the $\mathrm{ABTS}^{+}$activity. Fermentation process positively influenced variety 'Kilpatons' - total phenolic contents, vitamin C and antiradical activity $\left(\mathrm{ABTS}^{+} ; \mathrm{DPPH}\right)$ increased significantly. In variety 'Selma', fermentation process had little influence on total phenolic contents, but antiradical activity by $\mathrm{ABTS}^{+}$method and vitamin $\mathrm{C}$ content decreased. In variety 'Ramkila' - antiradical activity by $\mathrm{ABTS}^{+}$method decreased but total phenolic content and vitamin $\mathrm{C}$ increased.

\section{References}

1. Alberto M.R., Manca-deNadra M.C., Arena M.E. (2012) Influence of phenolic compounds on the growth and arginine deiminases system in a wine lactic acid bacterium. Brazilian Journal of Microbiology, Vol. 1517-8382, p. 167-176.

2. Gailīte M. (2018) Viss par labiem kāpostiem. Šķirnes, audzēšana, ražas, Agrotops. [accessed on 12.12.2018.]. Available at http://www.la.lv/jaunumi-kapostu-hibridupiedavajuma

3. Kampuse S., Ozola L., Straumite E., Galoburda R. (2015) Quality parameters of wheat bread enriched with pumpkin (Cucurbita Moschata) by-products. Acta Universitatis Cibiniensis, Series E: Food Technology, Vol. 19(2), p. 3-14.

4. Kriengsak T., Boonprakob U., Crosby K., CisnerosZevallos L., Byrne D.H. (2006) Comparison of ABTS, DPPH, FRAP, and ORAC assays for estimating antioxidant activity from guava fruit extracts. Journal of Food Composition and Analysis. Vol. 19 (6-7), p. 669-675.

5. Kusznierewicz B., Smiechowska A., Bartoszek A., Namiesnik J. (2007) The effect of heating and fermenting on antioxidant properties of white cabbage. Food Chemistry, Vol. 108, p. 853-861.

6. Kusznierewicz B., Bartoszek A., Wolska L., Drzewiecki J., Gorinstein S., Namiesnik J. (2008) Partial characterization of white cabbages (Brassica oleracea var. capitata f. alba) from different regions by glucosinolates, bioactive compounds, total antioxidant activities and proteins. LWT-Food Science and Technology, Vol. 41 (1), p. 1-9.

7. Lu Z., Breidt F., Plengvidhya V., Fleming H.P. (2003) Bacteriophage ecology in commercial sauerkraut fermentations. Applied and Environmental Microbiology, Vol. 69(6), p. 3192-3202.

8. Martinez-Villaluenga C., Peñas E., Frias J., Ciska E., Honke J., Piskula M.K., Kozlowska H., Vidal-Valverde C. (2009) Influence of fermentation conditions on glucosinolates, ascorbigen, and ascorbic acid content in white cabbage (Brassica oleracea var. capitata cv. Taler) cultivated in different seasons. Journal of Food Science, Vol. 74 (1), p. 62-67.

9. Martínez-Villaluenga C., Peñas E., Sidro B., Ullate M., Frias J., Vidal - Valverde C. (2012) White cabbage fermentation improves ascorbigen content, antioxidant and nitric oxide production inhibitory activity in LPSinduced macrophages. LWT-Food Science and Technology, Vol. 46 (1), p. 77-83

10. Palani K., Harbaum-Piayda B., Meske D., Keppler J.K., Bockelman W., Heller K.J., Schwarz K. (2016) Influence of fermentation on glucosinolates and glucobrassicin degradation products in sauerkraut. Food Chemistry, Vol. 190, p. 755-762.

11. Prasad N., Yang B., Kong K.W., Khoo H.E., Sun J., Azlan A., Ismail A., Romli Z.B. (2013) Phytochemicals and antioxidant capacity from Nypa fruticans Wurmb fruit. Evidence-Based Complementary and Alternative Medicine, Vol. 2013, p. 1-9.

12. Rodriguez-Amaya D.B. (2015) Vegetables as sources of nutrients and bioactive compounds: Health benefits. In: Handbook of Vegetable Preservation and Processing. 2nd ed. Y. H. Hui, E. O. Evranuz (eds). Boca Raton: CRC Press, p. 1-22.

13. Rodriguez H., Curiel J.A., Landete J.M., Rivas B., Lopez F., Gomez-Cordoves C., Mancheno J.M., Munoz R. (2009) Food phenolics and lactic acid bacteria. 
International Journal of Food Microbiology, Vol. 132(2-3), p. 79-90.

14. Rokayya S., Li C., Zhao Y., Li Y., Sun C. (2013) Cabbage (Brassica oleracea L. var. Capitata) Phytochemicals with antioxidant and anti-inflammatory potential. Asian Pacific Journal of Cancer Prevention, Vol. 14, p. 6657-6662.

15. Segliņa D. (2007) Sea buckthorn fruits and their processing products. Summary of promotion work for acquiring the Doctor's degree in Engineering Sciences in the Food Science. [accessed on 30.01.2019.]. Available at: summary/food/Kopsavilkums-2007-LLU-DalijaSeglina.pdf

16. Shalaby E.A., Shanab S.M.M. (2012) Comparison of DPPH and ABTS assays for determining antioxidant potential of water and methanol extracts of Spirulina platensis, Indian Journal of Geo-Marine Sciences, Vol. 42(5), p. 556-564.

17. Singh J., Upadhyay A.K., Bahadur A., Singh B., Singh K.P., Mathura Rai (2006) Antioxidant phytochemicals in cabbage (Brassica oleracea L. var. capitata). Scientia Horticulturae. Vol. 108 (3), p. 233-237.

18. Šamec D., Piljac-Žegarac J., Bogovič M., Habjanič K., Gruz J. (2011) Antioxidant potency of white (Brassica oleracea L. var. capitata) and Chinese (Brassica rapa $\mathrm{L}$. var. pekinensis (Lour.)) cabbage: The influence of development stage, cultivar choice and seed selection.
Scientia Horticulturae, Vol.128 (2), p.78-83.

19. Thakur P. K., Panja P., Das A., Kabir J. (2017) Varietal response to sauerkraut preparation. Journal of Crop and Weed, Vol. 13(2), p. 90-94.

20. Trail A.C., Fleming H.P., Young C.T., McFeeters R.F. (1996) Chemical and sensory characterization of commercial sauerkraut. Journal of Food Quality, Vol. 19, p. 567-568.

21. Vatansever S., Vegi A., Garden-Robinson J., Hall C.A.III (2017) The effect of fermentation on the physicochemical characteristics of dry-salted vegetables. Journal of Food Research, Vol. 6 (5), p. 32-40.

22. Viander B., Maki M., Palva A. (2003) Impact of low salt concentration, salt quality on natural large-scale sauerkraut fermentation. Food Microbiology, Vol. 20 (4), p. 391-395.

23. Wagner E.A., Rimbach G. (2009) Ascorbigen: chemistry, occurrence, and biologic properties. Clinics in Dermatology. Vol. (2), p. 217-224.

24. Yoon S. S., Barrangou-Poueys R., Breidt F., Jr., Klaenhammer T. R., Fleming H. P. (2002) Isolation and characterization of bacteriophages from fermenting sauerkraut. Applied and Environmental Microbiology, Vol. 68(2), p. 973-976. 